\title{
Peningkatan Kapasitas Fotografer Pemula Melalui Sekolah Fotografi Online (SeFO) Tingkat Jawa Timur Untuk Mewujudkan Fotografer Mahir dengan Handphone di Masa Pandemik Covid-19
}

\author{
Amang Fathurrohman ${ }^{1}$, Alfian Adi Saputra ${ }^{1}$, Fauziyah Rahmawati ${ }^{1}$, M. \\ Wildan Adnan ${ }^{1}$, M. Rifqi Nur Habibi ${ }^{1}$, Mochamad Hasyim ${ }^{2}$ \\ ${ }^{1}$ IAI Sunan Kalijogo Malang, ${ }^{2}$ Universitas Yudharta Pasuruan \\ amangfr@gmail.com, alfianadi1991@gmail.com, \\ fauziyahrahmawati91@gmail.com,wildanphreaker@gmail.com, \\ nhhabibi3@gmail.com, hasyim@yudharta.ac.id
}

\begin{abstract}
:
Condition Pandemic Covid-19 has forced the Indonesian citizen to stay at home. There are no exception for novice photographers who want to add their photography skills. Through e-Comdev, the team carried out a beginner photographer's capacity building assistance through the East Java level of online photography (SeFO) by utilizing WhatsApp social media to parse the problems faced with learning photography during the Covid-19 pandemic. The results of this mentoring show that SeFO participants still have a sense of innovation in improving the capacity of photography. Their skills are also increasingly well-honed in learning the basic photography skills, namely the composition, angle of view, and the explore of the types of photographs. The photo practice they have done is getting better in accordance with the basics of photographic theory. Guided by Tim and the material prepared well is helpful to the participants to understand the material well and feel the benefits of this mentoring more maximally
\end{abstract}

Keyword: Photography, Mobile, WhatsApp, pandemic Covid-19

\section{Pendahuluan}

Pandemik Covid-19 yang melanda dunia sejak Desember 2019. WHO menjelaskan bahwa COVID-19 adalah penyakit menular yang disebabkan coronavirus yang baru ditemukan dan menjadi Wabah di Wuhan, Tiongkok, bulan Desember 2019,(Pertanyaan dan jawaban terkait Coronavirus, 2020) dan terus menyebar di seluruh dunia, termasuk di Indonesia. Untuk mencegah penyebaran virus tersebut, masyarakat di Indonesia harus melakukan physical distance, School from Home, dan Work from Home. 
Dalam dunia fotografi, para fotografer juga merasakan dampaknya, mulai dari banyaknya agenda fotografer wedding dan ceremony yang di cancel, serta berbagai tempat wisata yang biasanya digunakan untuk spot foto juga ditutup oleh Pemerintah dan pengelola wisata. Termasuk agenda kegiatan pelatihan fotografi yang banyak digagas oleh berbagai komunitas juga tidak bisa diselenggarakan secara langsung.

Hal ini senada dengan apa yang disampaikan oleh Erwin Mulyadi, dalam tulisan essay Dampak Virus terhadap Fotografi yang menyatakan Covid-19 ini telah mempengaruhi dunia fotografi, mulai dari produksi alat, bahan pembuatan kamera, pembatalan pameran foto level dunia sebagaimana terlihat dalam gambar 1, dan juga berbagai event lainnya.(Mulyadi, 2020)

Para fotografer di Bali yang berbasis Wisata, dalam liputan Ni Luh Putu Wahyuni Sri Utami(Sari, 2020) melaporkan bahwa para fotografer di Bali banyak yang beralih profesi, atau setidaknya profesi utama bukan lagi bertumpu pada fotografi, namun beralih pada profesi lainnya karena Covid-19 telah berpengaruh besar menurunnya wisatawan di Bali dan ditutupnya tempat wisata di Bali.

Enche Tjin dalam tulisannya Dunia Fotografi Tak Akan Sama Lagi Setelah Corona? di detik.com juga menulis pesan yang sama, bahwa Covid-19 memukul para profesi fotografer. Lebih lanjut, Enche Tjin juga memberikan saran bagaimana melewati masa-masa Pandemik Covid-19, diantaranya merawat dengan baik alatalat kamera dan juga bisa melakukan belajar dan bereksperimen hal-hal baru, baik teknik fotografi dalam ruangan atau mengasah editing foto.(Tjin, 2020)

Dari latar belakang tersebut, maka Tim pendamping menginisiasi Peningkatan Kapasitas pada komunitas fotografer pemula tingkat Jawa Timur Melalui Sekolah Fotografi Online (SeFO).

\section{Metode}

Metode yang digunakan dalam pengabdian masyarakat ini adalah menggunakan pendekatan e-Comdev. Yakni proses pendampingan masyarakat 
Amang Fathurrohman, Alfian Adi Saputra, Fauziyah Rahmawati, dkk | 113

dilakukan melalui online untuk meningkatkan kapasitas Fotografer Pemula di Jawa Timur.

Penggunaan e-Comdev ini dilakukan karena saat dilakukan pendampingan ini Indonesia masih dalam kondisi Pandemic Covid-19 yang memaksa seluruh warga Negara Indonesia harus tetap berada di rumah, serta tidak memungkinkan adanya kontak langsung / pertemuan langsung antara Tim dengan para Fotografer yang ingin belajar. Adapun media online yang digunakan menggunakan media WhatsApp Group.

Tahapan-tahapan dalam e-Comdev ini dilakukan melalui beberapa tahapan sebagai berikut. (1) Pemetaan Kondisi dan Persiapan PkM, (2) sosialisasi Program SeFO dan Registrasi, (3) Persiapan Sekolah Fotografi Online, (4) Implementasi dan Praktek SeFO, (5) Evaluasi.

Kegiatan PkM ini dilaksanakan pada bulan April-Mei 2020, menitikfokuskan pada pengenalan dasar fotografer pada komposisi dan angle of view, serta mengenal beragam jenis fotografi. Untuk peserta kegiatan pengabdian masyarakat ini diikuti oleh 230 Peserta dari berabagai kalangan, baik pelajar, mahasiswa, guru, dosen, dan profesi lainnya di Jawa Timur, sebagaimana tersaji dalam grafik berikut ini.
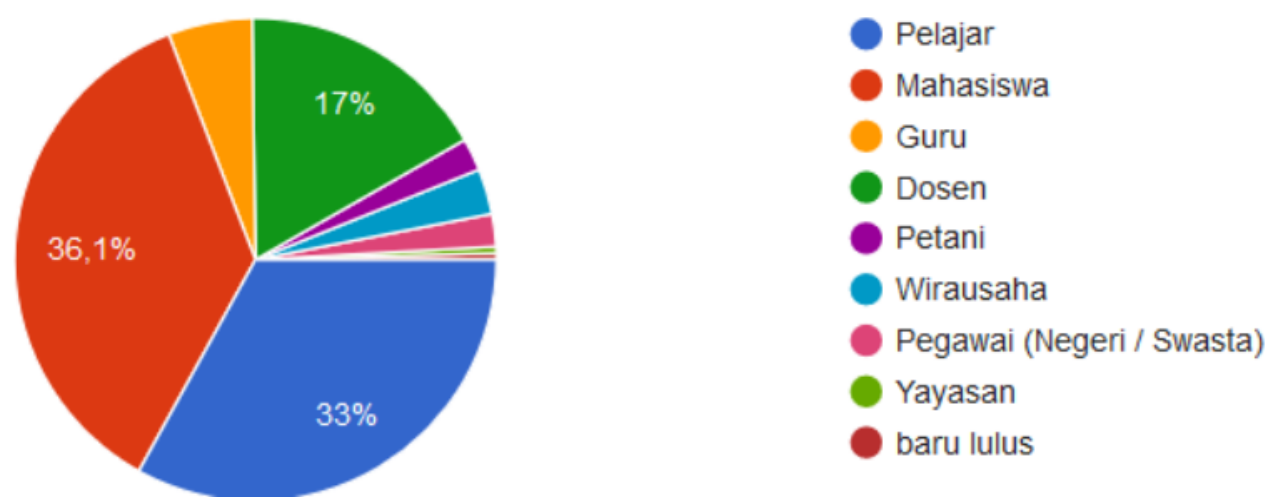

Dari grafik di atas, diketahui komposisi peserta Sekolah Fotografi Online yang terdiri dari Mahasiswa (36,1\%), Pelajar (33\%), Dosen (17\%), Guru (5,7\%), dan sisanya kalangan lainnya, seperti petani, pegawai, wirausaha, dan lain sebagainya. 
114 | Peningkatan Kapasitas Fotografer Pemula Melalui Sekolah Fotografi Online

\section{Hasil dan Diskusi}

\section{Pemetaan Kondisi dan Persiapan PkM}

Terjadinya Pandemic Covid-19 Sejak Desember tahun 2019 sampai terlaksananya kegiatan pengabdian masyarakat ini telah memaksa semua orang untuk belajar di rumah, bekerja di rumah, dan tidak dapat melaksanakan kegiatan yang bersifat massa. Hal ini juga berdampak terhadap para fotografer pemula untuk belajar.

Menyadari kondisi ini, maka Tim menginisiasi untuk melakukan pendampingan Peningkatan Kapasitas Fotografer Pemula Melalui Sekolah Fotografi Online (SeFO) Untuk Mewujudkan Fotografer Mahir Dengan Handphone Di Jawa Timur.

Tim menyadari bahwa pilihan untuk belajar melalui Online harus disesuaikan dengan target grup yang akan didampingi. Oleh karena itu, maka Tim memilih untuk menggunakan media Sosial WhatsAPP Grup sebagai media untuk belajar secara online teknik dasar fotografi.

Kelebihan media ini adalah sudah sangat familier dan dikenal oleh erbagai kalangan, namun kelemahannya peserta hanya dibatasi maksimal 256 saja.

\section{Sosialisasi Program SeFO dan Registrasi}

Setelah dilakukan pemetaan dan permusan materi pendampingan, langkah selanjutnya adalah melakukan sosialisasi program Sekolah Fotografi Online. Sosialisasi dilakukan dengan membuat pamflet kegiatan SeFO, informasi dasar, serta link WhatsAPP Grup yang bisa diikuti oleh para Fotografer Pemula. Sosialisasi tersebut cukup disebbar diberbagai grup Whatspp yang ada.

Dengan disoialisasikannyakegiatan $\mathrm{SeFO}$, maka berbagai kalangan yang ingin mengikuti kegiatan $\mathrm{SeFO}$ akan mengklik tautan Grup yang sudah disebarkan. Hasil tahap ini adalah pada tanggal 25 April 2020 Grup tergabung sebanyak 230 peserta 
Amang Fathurrohman, Alfian Adi Saputra, Fauziyah Rahmawati, dkk | 115

\section{Persiapan Sekolah Fotografi Online}

Kegiatan Sekolah Fotografi Online ini dilaksanakan dengan memanfaatkan grup pada whatsApp diawali dari pra pelatihan sebagai bagian dari persiapan bagi peserta untuk mengikuti Sekolah Fotografi Online. Persiapan ini dilakukan pada Senin, 27 April 2020.

Peserta diberi arahan dan pengantar terlebih dahulu mengenai SeFO oleh Tim, serta diberi kesempatan untuk mempersiapkan alat dan bahan yang akan digunakan selama tiga hari kedepan. Selain itu, peserta yang telah tergabung harus mengisi formulir peserta melalui google form yang telah disediakan oleh Tim

\section{Implementasi dan Praktek SeFO}

Implementasi dan praktek SeFO dilaksanakan pada tanggal 28-30 April 2020. Selama masa pendampingan, para fotografer yang tergabung dalam SeFO mempelajari tentang komposisi dalam fotografi.

Pengenalan komposisi dalam fotografi agar para peserta SeFO memiliki kemampuan dalam pengaturan letak dan perbandingan objek-objek yang mendukung dalam suatu foto agar tampak lebih menarik dan sedap dipandang (Saputra et al., 2020).
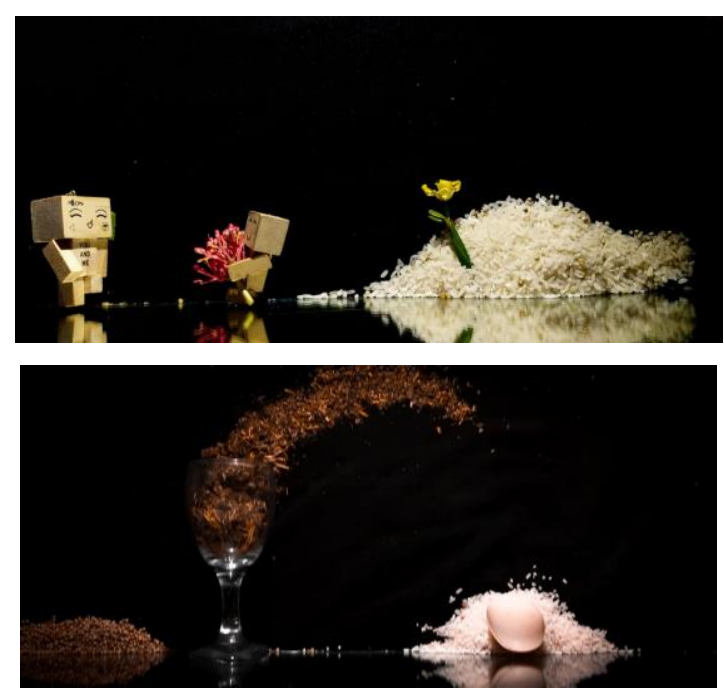

Gambar Sampel Hasil Praktek Fotografi melalui Sekolah Fotografi Online

Selain pengenalan komposisi, peserta juga mempelajari tentang materi 
ukuran dan angle of view. Para pesera berlatih bagaimana mengambil perspektif dan posisi yang tepat dalam mengambil gambar dengan HP. Pengambilan gambar dengan menempatkan sudut pandang yang tepat akan mampu menghasilkan foto yang baik. Misalnya ingin menampilkan objek menjadi besar, dramatis, atau bahkan ingin menampilkan objek menjadi kecil, maka sudut pandang menjadi kuncinya. Ada beberapa tips untuk melakukan praktik, diantaranya: Eye Level, High Angle, Low Angle (Saputra et al., 2020). Selain itu, mereka juga belajar dari kesalahan-kesalahan kecil yang sering dilakukan dalam pengambilan gambar.

Setelah mengenal dan mempraktekkan tentang materi komposisi dan angle of view, selanjutnya para peserta baru dikenalkan tentang beragam jenis-jenis foto. Dalam sesi ini tim mengenalkan lima macam jenis foto, yakni manusia, alam, arsitektur, still life, dan kreatifitas untuk dipraktekkan dan direview oleh Tim.

\section{Evaluasi Pendampingan}

Dari setiap tahapan yang sudah dilakukan oleh tim dalam pendampingan masyarakat ini, didapatkan hasil evaluasi pendampingan sebagai berikut:

Pertama, belajar fotografi menggunakan media Sosial WhatsAPP yang dikemas melalui SeFO (Sekolah Fotografi Online) telah dirasakan oleh para peserta kemanfaatannya, sebagaimana tersaji dalam grafik berikut:

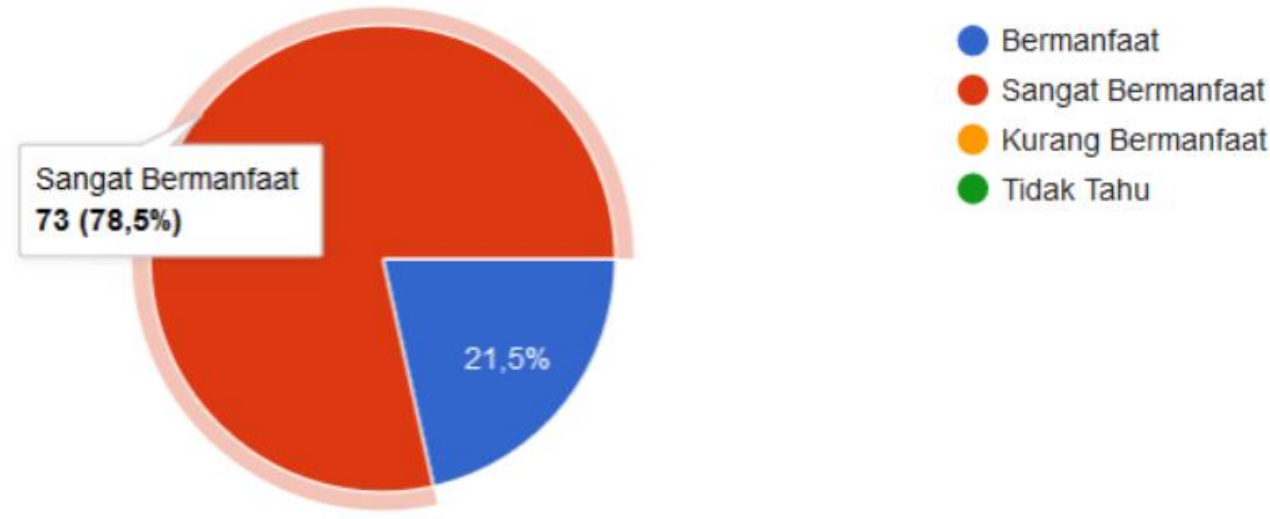

Dari grafik di atas, diketahui bahwa para peserta sangat merasakan bahwa SeFO yang telah mereka ikuti dirasakan sangat bermanfaat $(78,5 \%)$, dan bermanfaat $(21,5 \%)$, serta tidak ada satupun peserta yang merasakan kurang 
bermanfaat. Dengan demikian, maka agenda SeFO mampu menjadi pengobat rindu bagi mereka yang ingin tetap belajar fotografi di masa Pandemik Covid-19 ini, walau melalui media social WhatsAPP.

Kedua, respon peserta dalam form feedback, baik dari segi proses pemaparan materi, memahami materi, sampai peningkatan kapasitas dalam kemampuan fotografi para peserta SeFO, tersaji dalam grafik berikut:

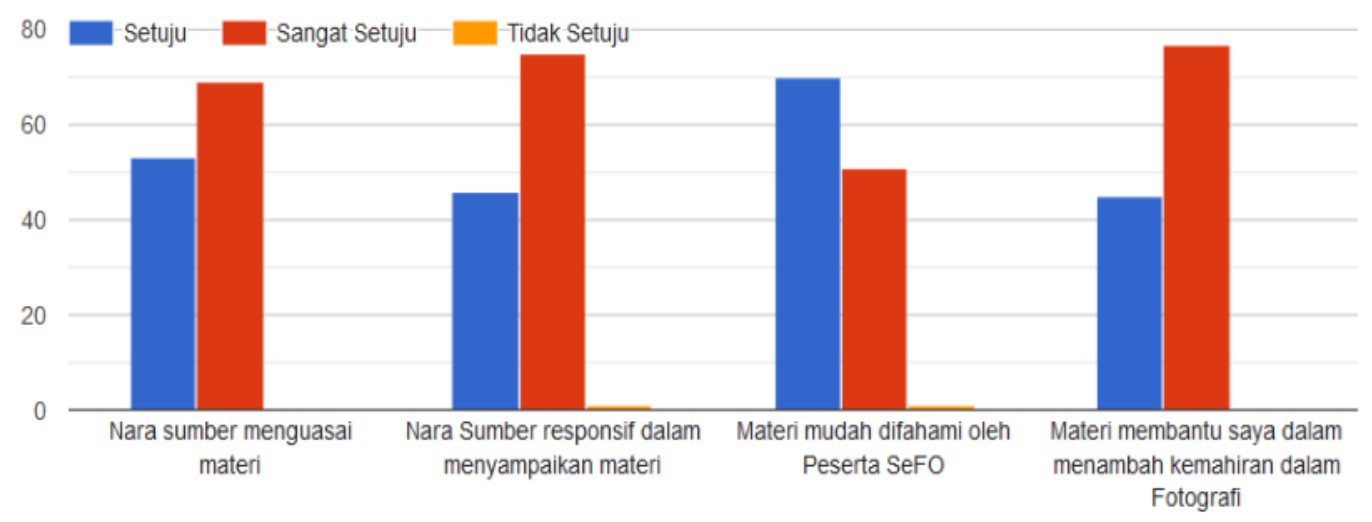

Dari grafik di atas, diketahui bahwa narasumber berkontribusi besar dalam kegiatan SeFO untuk mengantarkan dan memfasilitasi peserta. Hal ini dirasakan peserta bahwa mereka mampu memahami materi yang disampaikan dan mampu membantu menambah kemahiran mereka dalam skill fotografi yang mereka miliki.

\section{Kesimpulan}

Pendampingan Peningkatan Kapasitas Fotografer Pemula Melalui Sekolah Fotografi Online (SeFO) Tingkat Jawa Timur Untuk Mewujudkan Fotografer Mahir dengan Handphone di Masa Pandemik Covid-19 melalui media sosial WhatsAPP telah menjadi salah satu solusi dalam belajar Fotografi di masa pandemik Covid-19. Masyarakat yang mengikuti kegiatan SeFO, tetap memiliki sense inovasi dalam peningkatan kapasitas fotografi. Kemampuan mereka semakin terasah dengan baik dalam mempelajari skill dasar fotografi, yakni komposisi, angle of view, dan eksplore jenis-jenis foto. Hasil praktek foto yang telah mereka lakukan semakin baik sesuai dengan dasar-dasar teori fotografi. Dengan dipandu 
118 | Peningkatan Kapasitas Fotografer Pemula Melalui Sekolah Fotografi Online

oleh Tim dan dipersiapkan materinya dengan baik sangat membantu para peserta untuk memahami materi dengan baik dan merasakan manfaat pendampingan ini lebih maksimal.

\section{Ucapan Terma Kasih}

Ucapan terimakasih disampaikan kepada LPPM dan Prodi KPI IAI Sunan Kalijogo Malang serta Otak Lensa atas kerjasamanya dalam penyelenggaraan Sekolah Fotografi Online, sehingga pendampingan ini dapat terlaksana dengan baik.

\section{Daftar Pustaka}

Mulyadi, E. (2020). Dampak Virus Corona terhadap Fotografi. http://www.infofotografi.com/blog/2020/03/dampak-virus-corona-terhadapfotografi/

Pertanyaan dan jawaban terkait Coronavirus. (2020). WHO. https://www.who.int/indonesia/news/novel-coronavirus/qa-for-public

Saputra, A. A., Fathurrohman, A., \& Rahmawati, F. (2020). Langkah Mudah Mahir Fotografi dengan Handphone. IAI Sunan Kalijogo Malang.

Sari, N. L. P. W. (2020). Fotografer dan Videografer di Bali yang Terpaksa Alih Profesi Akibat Terdampak Pandemi Corona. Tribunnews. https://bali.tribunnews.com/2020/04/22/cerita-fotografer-dan-videografer-dibali-yang-terpaksa-alih-profesi-akibat-terdampak-pandemi-corona.

Tjin, E. (2020). Dunia Fotografi Tak Akan Sama Lagi Setelah Corona? Detik.Com. https://inet.detik.com/fotostop-news/d-4967705/dunia-fotografitak-akan-sama-lagi-setelah-corona 